Article

\title{
Sexism and Aggression in Adolescence-How Do They Relate to Perceived Academic Achievement?
}

\author{
Elisabeth Malonda *, Anna Llorca, Ana Tur-Porcar ${ }^{\circledR}$, Paula Samper and Ma Vicenta Mestre \\ Department of Basic Psychology, Faculty of Psychology, University of Valencia, 46010 Valencia, Spain; \\ anna.llorca@uv.es (A.L.); ana.tur@uv.es (A.T.-P.); paula.samper@uv.es(P.S.); maria.v.mestre@uv.es (M.V.M.) \\ * Correspondence: elisabeth.malonda@uv.es; Tel.: +34-963-864150
}

Received: 21 June 2018; Accepted: 21 August 2018; Published: 24 August 2018

\begin{abstract}
Sexist attitudes are rooted in patriarchal structures, which uphold traditional gender stereotypes, and which are still found in society today. Scholars have found gender differences in perceived academic achievement, with girls performing better than boys, and negative relationships between sexism and perceived academic achievement. Moreover, perceived academic achievement and sexist attitudes have been associated with aggression and different kinds of violence. This study examined the associations between sexist attitudes and perceived academic achievement (using self-report data). The study also assessed the mediating role of physical and verbal aggression in the relationship between sexist attitudes and perceived academic achievement. Seven hundred eight Spanish adolescents participated in the study. The mean age was $13.00(S D=0.95$; range $=12-14$ years). Structural equation modelling (SEM) was used to analyse the effects among variables for boys and girls. Results showed the role of benevolent sexism and hostile sexism in perceived academic achievement, as well as the mediating role of aggression in the relationship between sexism and perceived academic achievement. Findings and implications are discussed to assess measures for establishing intervention programs and educating adolescents in a non-sexist manner.
\end{abstract}

Keywords: hostile sexism; benevolent sexism; perceived academic achievement; physical and verbal aggression; adolescence

\section{Introduction}

Scholars have found gender differences in academic achievement, with girls performing better than boys [1,2], and negative relationships between sexism and academic achievement [3-5]. These relationships hold mainly for adolescent girls who live in traditional environments where women are responsible for most domestic chores [3-5]. In today's society, sexist attitudes are common among adolescents [5-7]. Sexism is rooted in patriarchal structures, and it encourages traditional gender stereotypes [8,9]. Furthermore, researchers have found relationships between sexist attitudes and different kinds of violence [10-12]. In addition, consistent evidence for the link exists between aggression and academic self-efficacy [13-15]. Therefore, might sexist attitudes also be associated with perceived academic achievement in boys? Might there be differences between hostile sexism and benevolent sexism when related to perceived academic achievement? Might aggression act as a mediating variable between sexist attitudes and perceived academic achievement? In the present study, we first examined the relationships between sexist attitudes, segregating hostile sexism and benevolent sexism, with academic achievement in Spanish adolescent boys and girls. Second, we analysed the mediating role of physical and verbal aggression in the relationship between sexist attitudes and academic achievement in early adolescence. Aggression is a vulnerability factor $[13,16]$. 


\subsection{Sexist Attitudes}

Sexist attitudes refer to negative gender-based evaluations that foment inequality between men and women [17]. From a biosocial perspective, sexist attitudes are based on sexual differences and the interactions among the physical attributes of men and women and the social contexts in which people live [18].

The theory of ambivalent sexism $[19,20]$ posits that sexism comprises hostile sexist attitudes (i.e., prejudiced beliefs that women are inferior) and benevolent sexist attitudes (i.e., ostensibly positive attitudes that idealize women as mothers, wives, and romantic trophies). Hostile sexist attitudes and behaviours are open, visible, and explicit, while the attitudes and behaviours encompassed by benevolent sexism are more subtle and less visible. These two types of sexist attitudes have contrasting affective tones, yet, at the same time, they are related. Despite these differences, both forms of sexism are rooted in patriarchal cultures, and serve to legitimize traditional gender roles. Glick and Fiske (1996) [19] found that people with sexist attitudes might actually have hostile and benevolent sexist attitudes.

Personal, situational, and cultural factors intervene in the construction of identity. Cultural factors are materialized through expectations, norms, roles, values, beliefs, attitudes, and behaviours, which establish categories that cognitively affect the perceptions and attributions made by people both on themselves and on other people [21,22]. In this way, sexist attitudes might be related to self-concept and the direction and management of one's own actions [21,23].

In Spain, the emergence of democracy roughly 40 years ago sparked changes that have since made gender equality a political priority [24]. Although equality has not yet been fully achieved, these sociopolitical changes have facilitated a gradual shift towards equality in gender stereotypes [25]. Regardless, gender stereotypes prevail in other societies, as reported by numerous researchers [6,26,27]. Sexist attitudes reflect ambivalent feelings about gender discrimination and full gender equality $[9,28]$.

\subsection{Perceived Academic Achievement}

Researchers have shown scientific evidence for the associations between academic self-efficacy and academic achievement [14,29]. Regarding academic achievement, in Spain, girls have been shown to have higher levels of academic achievement than boys during early and middle adolescence [30]. In addition, girls have shown greater motivation and have assessed teaching staff more favourably than boys have. Boys, in contrast, have shown less motivation and have assessed teaching staff more negatively than girls have [31]. Other studies in child and university student populations report similar findings [32,33]. Differences between boys' and girls' socialization processes, which facilitate the adoption of culture-related gender-specific behaviours, encourage different behavioural patterns in terms of academic achievement [34]. It has nonetheless been shown that women (aged 25 to 42 years old) exposed to higher levels of sexism had lower levels of academic achievement owing to the mental intrusions women experienced regarding their perceptions of academic ability [35].

Likewise, scholars have found an association between sexist attitudes and poor academic achievement $[3,35]$. The influence of a sexist social and familial environment means that women are less likely than men to enrol in higher education courses that are highly specialized and highly qualified. Studies report these tendencies in Canada [5], the United States [3,36], and Spain [37]. Sexist environments affect women's expectations of having a career and encourage women to take on traditional, family-focused roles.

Research has found that women who perceived more benevolent sexist attitudes had lower intentions to study careers in sciences, technology, engineering, and mathematics, lower academic self-efficacy, and lower academic achievement. Likewise, perceived hostile sexism was related to low levels of academic achievement [38-40]. While for hostile sexism women havean inferior competence compared to men, for benevolent sexism, which is more subtle than hostile sexism, women are associated with the relational domain and communal values and men with the achievement domain and agentic values [19]. Researchers have focused mainly on the relationship between benevolent sexism and academic achievement presented in girls. The findings of some of the studies showed that 
the benevolent sexism of the adolescents is related to the manifestation of less interest in academic studies or a professional career. In contrast, they manifested more goals related to the traditional feminine occupations. In this way, the traditional expectations of the girls are reflected in their academic achievement [37]. In another investigation carried out in the United States, Rudman and Heppen (2003) [36] found that girls who supported chivalrous behaviour, a central aspect of benevolent sexism, showed less interest in pursuing a professional career. Thus, benevolent sexism might limit the academic goals of girls. In this regard, a study carried out with young Belgian women found that benevolent sexism was related to a worse cognitive performance and this was explained by the mental intrusions that said benevolent sexism projected on the academic competence of women [35].

The relationship between sexism and perceived academic achievement is based on socio-cognitive models that are founded on self-fulfilling prophecy [41] that expose people to build their self-concept through the internalization of social expectations including gender prescriptions and sexist socialization patterns. Similarly, stereotyped schemes condition attitudes and actions, and this reinforces the starting beliefs. Finally, the behaviour closes the self-fulfilment cycle [42].

In light of the prevalence of sexism and its negative associations with achievement motivation to obtain better academic qualifications [43], it is necessary to continue analysing the factors that contribute to ongoing gender inequality, as well as to analyse the factors that contribute to poor academic achievement.

Adolescents with poor academic achievement are at risk of dropping out of school, which may place them in a situation of social risk [1,44]. A lack of basic education can harm adolescents and is associated with performing low-skilled, undemanding jobs, which provide little personal satisfaction. Such circumstances place individuals at risk of developing unstable relationships [45,46].

\subsection{Aggression}

Regarding sexist attitudes and their relationship with aggressive behaviours among adolescents, in the last decade, psychologists have reported relationships between sexist attitudes and different kinds of aggression and violence [12], such as gender violence [47] and bullying at school [48,49], and the justification of violence $[11,47,50]$. Recently, it has been found that men who more strongly endorsed hostile sexism were more aggressive toward their female partners when their female partners were perceived to be low in relationship commitment [51].

In this study, we examined aggression as a component of the school environment, without restricting student responses [52]. Some authors distinguish between physical and verbal aggression. Physical aggression refers to physical confrontation between two people (e.g., hitting and pushing), whereas verbal aggression refers to aggression using language (e.g., insults and threats) [53].

In addition to the relationships discussed in the previous paragraph, aggression has also been linked to academic achievement [13-15].

\subsection{Aims and Hypotheses}

The aim of this study was to analyse the relationships between hostile and benevolent sexism and perceived academic achievement. The study examined how verbal and physical aggression mediated the relationship between sexist attitudes and perceived academic achievement in early adolescence. It is important to study both sexism and perceived academic achievement in adolescence for several reasons. First, adolescents are more conscious of the injustices of sexism, so adolescence is the ideal time in which to question social models and expectations regarding gender and sexism [54]. Second, sexist attitudes are related with different kinds of violence [10-12] Third, aggression is a vulnerability factor, which has been negatively associated with academic achievement [13]. Four, poor academic achievement is a social risk factor [1].

Through this research, we hope to find evidence to support the following hypotheses: (1) Benevolent and hostile sexism will be negatively related to perceived academic achievement, in both sexes. (2) Aggression will mediate the relationship between sexism (hostile and benevolent) and perceived 
academic achievement, acting as a vulnerability factor for perceived academic achievement, in both sexes. (3) Hostile sexism and aggression will mediate the relationship between benevolent sexism and perceived academic achievement, acting as vulnerability factors for perceived academic achievement, in adolescence.

The following model was tested (Figure 1):

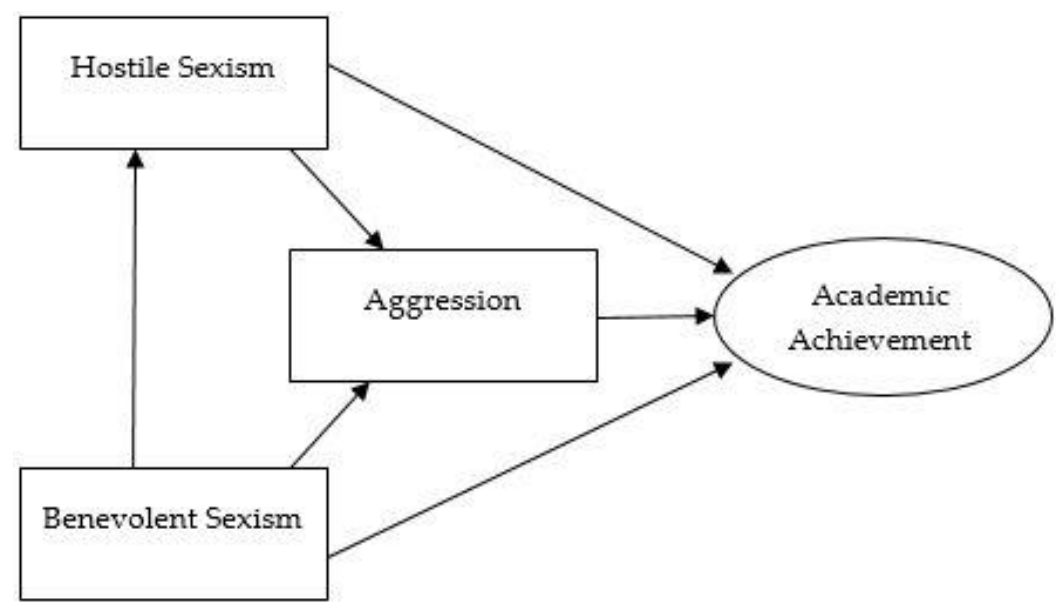

Figure 1. Visual representation of the proposed model. Academic achievement $=$ Perceived academic achievement.

\section{Materials and Methods}

\subsection{Participants}

The study's participants included 708 adolescents aged 12 to 14 years $(M=13.00 ; S D=0.95$; 338 boys, $47.7 \%$, and 370 girls, $52.3 \%$ ). Participants were high school students enrolled in schools in Valencia (Spain). Students were enrolled in public (state) schools (45.8\%) and semi-private schools $(54.2 \%)$. Almost $80 \%$ of thestudy participants was made up of Spanish adolescents. The remaining $20 \%$ belonged to individuals originating from Latin America (12.2\%), Eastern Europe (3.5\%) and North Africa (3\%), Southeast Asia (0.9\%), and Sub-Saharan Africa (0.4\%). With regard to the level of studies, participants were studying the first cycle of the obligatory secondary education. Regarding the educational attainment of the students' fathers, $9 \%$ of fathers had no formal education, $28 \%$ had completed primary education, $31.4 \%$ had completed high school education, and $31.6 \%$ had completed higher education. Regarding the educational attainment of the students' mothers, $6.2 \%$ of mothers had no formal education, $30.1 \%$ had completed primary education, $33.4 \%$ had completed high school education, and $30.3 \%$ had completed higher education (Table 1 ).

Table 1. Sample Demographic Characteristics.

\begin{tabular}{lcc}
\hline Sample, Variable, Group & $n$ & $\%$ \\
\hline Sex & & \\
$\quad$ Female & 370 & 52.3 \\
$\quad$ Male & 338 & 47.7 \\
\hline Type of centre & & \\
$\quad$ Public & 324 & 45.8 \\
$\quad$ Semi-private & 384 & 54.2 \\
\hline Family structure & & \\
$\quad$ One-parent families & 194 & 27.4 \\
$\quad$ Two-parent families & 514 & 72.6 \\
\hline
\end{tabular}


Table 1. Cont.

\begin{tabular}{lcc}
\hline Sample, Variable, Group & $\boldsymbol{n}$ & $\mathbf{\%}$ \\
\hline Level of studies & & \\
$\quad$ First year of secondary school & 330 & 46.6 \\
Second year of secondary school & 378 & 53.4 \\
\hline Ethnic origin & & \\
$\quad$ Spanish & 566 & 80.0 \\
Latin America & 86 & 12.2 \\
Eastern Europe & 25 & 3.5 \\
North Africa & 22 & 3.0 \\
Southeast Asia & 6 & 0.9 \\
Sub-Saharan Africa & 3 & 0.4 \\
\hline Father's education level & & \\
$\quad$ No formal education & 64 & 9.0 \\
Primary education & 198 & 28.0 \\
High school education & 222 & 31.4 \\
University studies & 224 & 31.6 \\
\hline Mother's education level & & \\
$\quad$ No formal education & 44 & 6.2 \\
Primary education & 213 & 30.1 \\
$\quad$ High school education & 236 & 33.4 \\
University studies & 215 & 30.3 \\
\hline
\end{tabular}

\subsection{Procedure}

We selected participating centres using simple random sampling based on the type (public/state vs. semi-private) and location of the school in the Valencian metropolitan area, as well as their classification as non-university centres of compulsory secondary education and further education. This approach ensured that all geographic regions were represented by the sample. The study was a cross-sectional study using student self-report data. Next, a letter was sent to the local government requesting our permission to work with the chosen schools. School principals were contacted by telephone and in writing. The letter sent to principals introduced the content of the study, aims, and target population and requested the schools' collaboration. Next, visits were made to the schools to provide information to the teachers. Once the principals had agreed to collaborate, we sent letters to parents describing the study. The letter requested permission for the adolescents to participate in the study. All subjects gave their informed consent for inclusions before they participated in the study. After obtaining permission from parents and adolescents, we collected the data and evaluated the adolescents in the classroom. The evaluations lasted approximately one hour. The trained evaluators for this study explained the evaluation instruments and gave instructions so that students were able to complete the questionnaires. At the end of the assessments, the questionnaires were reviewed by evaluators so that there were no items left unanswered. In this study, ethical guidelines were followed to ensure the anonymity of the respondents during data collection and analysis, following the rules of the Declaration of Helsinki of 1975, revised in 2008.

\subsection{Instruments}

\subsubsection{Benevolent and Hostile Sexism}

Sexist attitudes were evaluated using the Ambivalent Sexism Inventory for Adolescents [55]. This instrument is an adaptation for an adolescent population of the hostile and benevolent sexism inventory by Glick and Fiske (1996) [19]. Students indicated their agreement with 20 statements. They marked their responses on a scale ranging from 1 (strongly disagree) to 6 (strongly agree). An example item for hostile sexism was, "Boys should decide who their girlfriends see," and an 
example item for benevolent sexism was, "Girls are more aware of others' feelings than boys are." In the present study, Cronbach's alpha was 0.88 . Results for the goodness-of-fit statistics for the questionnaire were as follows: $\chi^{2}=330.039 / 89, p<0.001$; CFI (Comparative fit index) $=0.907$; SRMR (Standardized Rood Mean Square Residual) $=0.075$.

\subsubsection{Perceived Academic Achievement}

Perceived academic achievement was evaluated using five items reported by students. The items were: (1) high academic achievement (perception of the mean of the student's grades); (2) motivation and interest in school work; (3) whether the student can be considered a good student; (4) pace of work; and (5) regular class attendance. Academic achievement is more than a student's grade point average. Several factors such as motivation, socially accepted behaviours as prosocial behaviours, effort, student engagement, and responsibility indicate a student's academic achievement [56-58]. The items that we have used to evaluate perceived academic achievement are related to these factors. Students responded to each item on a scale ranging from 1 to $10(1=$ minimum; $10=$ maximum $)$. Cronbach's alpha was 0.79 for the students' self-report. Results for the goodness-of-fit statistics for the questionnaire were as follows: $\chi^{2}=60.414 / 16, p<0.001 ; \mathrm{CFI}=0.980$; SRMR $=0.076$.

\subsubsection{Aggression}

Aggression was evaluated using the Physical and Verbal Aggression Scale $[59,60]$. This instrument uses 15 items to evaluate behaviour that physically and verbally harms others. Respondents had three response alternatives ( $3=$ often, $2=$ sometimes, or $1=$ never $)$ according to the frequency with which the behaviour occurred. An example item was, "I speak badly about my classmates." Cronbach's alpha in this study was 0.87 . Results for the goodness-of-fit statistics for the questionnaire were as follows: $\chi^{2}=215.603 / 64, p<0.001 ; \mathrm{CFI}=0.912 ;$ SRMR $=0.070$.

\subsection{Data Analysis}

First, SPSS 24 was used to observe the differences in means and standard deviations for all variables under study. Next, Pearson correlation analysis was carried out to analyse the degree of relation and the relational tendency among variables. Then, the fit of the theoretical method designed through Structural Equation Models (SEM) was tested in Mplus 6.1 [61]. The following robust statistics were used to determine the goodness of fit: the chi-squared compared with the degrees of freedom $\left(\chi^{2} / \mathrm{df}\right)$, the robust comparative fit index (CFI robust comparative fit index), and the root mean residual (RMR) [62]. In addition, to test moderation by gender, we built two multigroup structural equation models-one for boys and one for girls. Finally, follow-up tests were used to examine the significance of indirect effects [63].

\section{Results}

\subsection{Descriptive Analyses}

We performed the $t$ test for independent samples. Table 2 shows the differences in means for all variables under study (benevolent sexism, hostile sexism, physical and verbal aggression, and perceived academic achievement according to self-report data).

Table 2. Means and standard deviations for boys and girls aged 12-14 years.

\begin{tabular}{|c|c|c|c|c|c|c|c|}
\hline \multirow{2}{*}{ Study Variables } & \multicolumn{2}{|c|}{ Boys } & \multicolumn{2}{|c|}{ Girls } & \multirow[b]{2}{*}{$t$} & \multirow[b]{2}{*}{$p$} & \multirow[b]{2}{*}{$d$} \\
\hline & $M$ & $S D$ & $M$ & $S D$ & & & \\
\hline Hostile Sexism & 3.80 & 1.09 & 2.55 & 0.94 & 16.53 & 0.000 & 1.15 \\
\hline Benevolent Sexism & 4.27 & 1.08 & 4.11 & 1.15 & 1.97 & 0.049 & 0.14 \\
\hline Physical and verbal aggression & 1.49 & 0.36 & 1.35 & .29 & 5.77 & 0.000 & 0.42 \\
\hline Perceived academic achievement & 6.72 & 1.58 & 7.44 & 1.49 & 22124.77 & 0.000 & 0.46 \\
\hline
\end{tabular}


Boys scored more highly in hostile and benevolent sexist attitudes and in aggression than girls did. The differences for these variables were significant. The effect size was large for hostile sexism (Cohen's $d=1.15$ ), medium for physical and verbal aggression (Cohen's $d=0.42$ ), and it was small for benevolent sexism (Cohen's $d=0.14$ ). Perceived academic achievement was higher for girls than for boys. These differences were statistically significant. The effect size was medium for perceived academic achievement according to student self-report data (Cohen's $d=0.46$ ) [64].

A correlation matrix of all variables used in this study is shown in Table 3. For boys, hostile sexism correlated negatively with perceived academic achievement, according to the self-report data $(r=-0.12, p<0.05)$. Conversely, hostile sexismSt correlated positively with physical and verbal aggression $(r=0.15, p<0.01)$. Benevolent sexism correlated positively with hostile sexism $(r=0.45$, $p<0.01)$.

Table 3. Correlation analysis for boys and girls aged 12-14 years.

\begin{tabular}{lcccc}
\hline \multicolumn{1}{c}{ Study Variables } & $\mathbf{1}$ & $\mathbf{2}$ & $\mathbf{3}$ & $\mathbf{4}$ \\
\hline 1. Hostile Sexism & - & $0.54^{* *}$ & $0.15^{* *}$ & $-0.17^{* *}$ \\
2. Benevolent Sexism & $0.45^{* *}$ & - & $0.10^{*}$ & $-0.11^{*}$ \\
3. Physical and verbal aggression & $0.15^{* *}$ & 0.05 & - & $-0.25^{* *}$ \\
4. Perceived academic achievement & $-0.12^{*}$ & -0.04 & $-0.28^{* *}$ & - \\
\hline
\end{tabular}

Note. ${ }^{* *} p<0.01,{ }^{*} p<0.05$. Results for girls appear to the upper-right of the diagonal; results for boys appear to the lower-left of the diagonal.

For girls (Table 3), hostile sexism correlated negatively with perceived academic achievement, according to the self-report data $(r=-0.17, p<0.01)$. Likewise, hostile sexism was positively related to physical and verbal aggression $(r=0.15, p<0.01)$. Benevolent sexism correlated positively with hostile $\operatorname{sexism}(r=0.54, p<0.01)$ and aggression $(r=0.10, p<0.05)$. Conversely, benevolent sexism correlated negatively with perceived academic achievement $(r=-0.11, p<0.05)$.

The correlations show that hostile sexism was strongly positively associated with benevolent sexism, both in boys and girls. Furthermore, the relationship had a higher significant level in girls. Additionally, the results suggest that hostile sexism was negatively related to perceived academic achievement in both sexes. This relationship had a higher significant level in girls. In contrast, while benevolent sexism was negatively related to perceived academic achievement only in girls, in boys, benevolent sexism had no significant correlation to perceived academic achievement. In addition, hostile sexism was negatively related to physical and verbal aggression in both sexes. Contrary to these results, the relationship between benevolent sexism and aggression was weak in girls and non-significant in boys. Finally, perceived academic achievement was negatively related to aggression, both in boys and girls.

\subsection{Structural Equation Models}

After defining the variables, we calculated the structural equation model to analyse the links between benevolent and hostile sexism and perceived academic achievement. The measurement of perceived academic achievement consisted of student self-report data. The mediating variable was physical and verbal aggression. Benevolent sexism, hostile sexism, and aggression were observed variables, whereas perceived academic achievement was a latent variable.

The goodness-of-fit indices of the structural equation model, as shown in Table 4, were as follows: $\chi^{2}=82.65 / 24, p<0.000$; CFI $=0.95$; TLI (Tucker Lewis index) $=0.93$; RMSEA (Root mean square error of approximation $)=0.05 ; \operatorname{SRMR}($ Standardized Rood Mean Square Residual $)=0.03$. Chi-square divided by degrees of freedom should be close to 3, root mean residual (RMR) and root mean square error of approximation (RMSEA) should be less than 0.08 [65], and the remaining robust statistics should be greater than 0.90 [66]. In this study, the values of the goodness-of-fit indices were acceptable. Thus, the model had a good fit to the data and was suitable for use with the sample of early adolescents. 
Table 4. Goodness-of-fit indices (structural equation model).

\begin{tabular}{cccccc}
\hline & $\chi^{2}$ & CFI & TLI & RMSEA & SRMR \\
\hline Structural equation model & $82.65 / 24 ; p<0.000$ & 0.95 & 0.93 & 0.05 & 0.03 \\
\hline
\end{tabular}

Note. CFI = Comparative fit index; TLI = Tucker Lewis index; RMSEA = Root mean square error of approximation; SRMR = Standardized Rood Mean Square Residual.

Figure 2 shows the structural equation model with standardized coefficients and associated probabilities. Benevolent sexism was positively associated with hostile sexism $(\beta=0.45)$. Likewise, hostile sexism was negatively associated with perceived academic achievement $(\beta=-0.17)$ and positively associated with physical and verbal aggression $(\beta=0.24)$. In addition, physical and verbal aggression was negatively associated with perceived academic achievement $(\beta=-0.33)$. The weight was largest for the association between benevolent and hostile sexism, second largest for the association between aggression and perceived academic achievement, and smaller for the associations between hostile sexism and perceived academic achievement, and aggression.

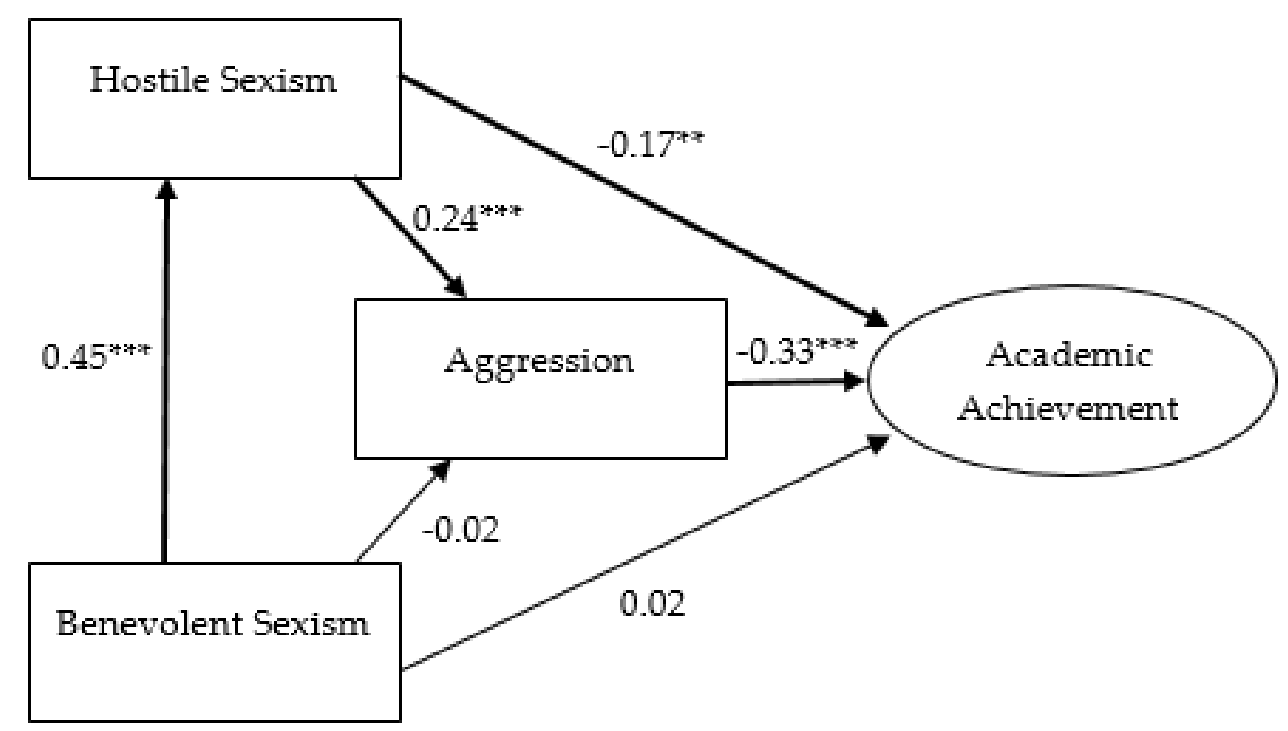

Figure 2. Structural equation model. Standardized values. ${ }^{* *} p<0.01$; ${ }^{* * *} p<0.001$. Academic achievement $=$ Perceived academic achievement. Bold paths depict significant indirect effects.

Bias corrected bootstrap confidence intervals suggested that there was a significant indirect effect from benevolent sexism to perceived academic achievement $(\beta=-0.08$; CI 95\% $=[-0.12$, $-0.03])$ via hostile sexism because it did not include zero. If the confidence interval does not include zero, the null hypothesis of no mediation is rejected, providing empirical support for the indirect effect. There was also a significant effect from benevolent sexism to perceived academic achievement $(\beta=-0.03 ;$ CI $95 \%=[-0.05,-0.02])$ via hostile sexism and aggression. The indirect effect was also significant for the link between hostile sexism and perceived academic achievement $(\beta=-0.08$; CI 95\% $=[-0.12,-0.04])$ via aggression.

Next, we tested our model for boys and girls and analysed the relationship among variables. To do so, we built two multigroup structural equation models-one for boys and one for girls.

In testing moderation by gender, the unconstrained model $\left[\chi^{2}(58)=102.47\right]$ and the constrained model $\left[\chi^{2}(64)=103.92\right]$ were not significantly different, as determined by a chi-square difference test $\left[\chi^{2}(6)=0.50, p=0.99\right]$, suggesting no moderation by gender. 


\section{Discussion}

The first aim of this study was to analyse the relationships between sexism, hostile and benevolent sexism, and perceived academic achievement. The second aim was to examine how verbal and physical aggression in early adolescence mediated the aforementioned relationships.

Results suggest that hostile sexism is negatively related to perceived academic achievement in both sexes. However, benevolent sexism was negatively related to perceived academic achievement only in girls (Hypothesis 1). In boys, benevolent sexism had no significant correlation to perceived academic achievement. The results correlate with those from previous studies; scholars have reported that negative relationships between sexism and academic achievement mainly affect girls [3,4], for whom sexism creates barriers to academic goals and, by extension, to girls' education and professional careers [37]. The dominant explanation for such gender discrimination is the influence of the social and family environment, which limits girls' academic goals and teaches girls to prioritize family responsibilities [3,36,37]. This discrimination creates barriers for girls for the chance to enrol in higher technical education, which would allow them to achieve highly qualified technical jobs. These results confirm that benevolent sexism is associated with traditional gender roles, which associate women with communal values (e.g., concern for others) and men with agentic values (e.g., competence), which might be the reason why benevolent sexism had no significant relationship with perceived academic achievement in boys and it was negatively related to perceived academic achievement in girls $[19,40]$.

The study highlighted the mediating role of physical and verbal aggression in the relationship between hostile sexism and perceived academic achievement (Hypothesis 2). Hence, physical and verbal aggression in plain view of others (i.e., hitting and insulting others) is a risk factor for academic achievement, enhanced by hostile sexist attitudes. Girls and boys with higher scores for hostile sexism who were also more aggressive were at a higher risk of experiencing problems with their academic achievement. Externalizing behaviour problems was negatively related to poor academic achievement $[13,67]$. Although there were not significant differences in the studied model according to sex, this is where males may be more disadvantaged than females, given their higher scores in hostile sexism and aggressiveness. Sexism legitimises traditional gender stereotypes [8,9], which associate males with psychological traits linked with masculinity (e.g., aggression and a tendency to dominate). In addition, the relationship between benevolent sexism and aggression is weak in girls and non-significant in boys. Benevolent sexism takes the form of being apparently positive and motivates behaviours of help and protection toward women. It is apparently accepted by society given the protective nature toward women [19]. This might be an explanation of the lack of relationship between these variables.

The findings presented in this paper indicate that sexism and poor perceived academic achievement are present in both boys and girls. This supports the view that sexism legitimates specific attributes for men and women $[2,25,68,69]$, along with factors rooted in patriarchal societies [9]. It is also important to note the negative relationship between hostile sexism and perceived academic achievement in boys and girls. However, the relationships have a higher significant level in girls. Moreover, as also observed with aggression, the relationship between benevolent sexism and perceived academic achievement is weak in girls and non-significant in boys. Socio-cognitive models indicate that people build their self-concept through the internalization of social discourse, which includes sexist attitudes [41,42]. Furthermore, sexist attitudes encourage traditional gender roles [8,9].

Previous findings indicate that boys scored more highly in sexism [70] and were more likely to have disciplinary problems at school, contributing to poor academic achievement [32,33]. In the present study, boys had lower scores for perceived academic achievement than girls did, as seen in other research [1].

It is also important to take into account the effects of benevolent sexism, due to its high relationship with hostile sexism. Despite its positive appearance, in this study benevolent sexism was a predictor of perceived academic achievement in both sexes, through hostile sexism and aggressiveness (Hypothesis 3), following other studies [37] where the importance is highlighted to make adolescent 
women aware of the influence of the internalization of benevolent sexist beliefs on the future academic and career opportunities of female adolescents, in order to allow women to challenge and reject them, and the contribution of benevolent sexism to perpetuating gender inequality over generations [9]. However, the results in the model did not show direct relationships between benevolent sexism and perceived academic achievement. According to the theory of ambivalent sexism [19,20], hostile sexist attitudes and benevolent sexist attitudes have contrasting affective tones, yet, at the same time, they are related. In fact, people with sexist attitudes might actually have hostile and benevolent sexist attitudes.

In summary, hostile and benevolent sexist attitudes hinder the academic achievement of adolescent girls and boys [21,23]. Moreover, hostile sexism can become a risk factor for aggressive behaviour [11,12,47,50], which may also affect academic achievement [13-15], and benevolent sexism can become a risk factor for hostile sexism. In adolescent girls and boys, this relationship may be mediated by physical and verbal aggression. Therefore, benevolent sexism has a clear role in academic performance through hostile sexism and aggression.

\section{Strengths, Limitations, and Future Directions}

The results obtained in this study confirm the relationships between hostile sexism and perceived academic achievement, as well as the mediating role of hostile sexism and aggression between benevolent sexism and academic achievement in both sexes. Likewise, the direct relationship between aggression and academic achievement is confirmed. In addition, although benevolent sexism is negatively related to perceived academic achievement only in girls, the results support that there are hardly any differences between boys and girls with regard to the relationships between sexism and academic achievement, when aggressiveness is a mediator, and therefore, sexism is also harmful to the perceived academic achievement of boys, which is one of the strengths of this study. These findings reveal the need to tackle sexism when designing plans to improve academic achievement in adolescence.

Despite yielding valuable findings, the current study had some limitations. The data were crosssectional, which prevented the identification of causal relationships among variables. Longitudinal studies are needed to establish such relationships. A second limitation is a product of the information sources. All variables except academic achievement were obtained using self-report data. The study could be enriched by using two data sources for all variables. A third limitation stems from the decision to analyse data for just two large groups of the population (i.e., girls and boys).

Despite the limitations of the study, the findings provide a platform for further analysis of the relationships between sexist attitudes and academic achievement. For instance, it would be of interest to understand the mediating role of gender in the achievement motivation across all subjects in the curriculum [3]. Boys and girls could thus gain access to higher education courses focused purely on each student's personal interests and skills.

Sexist attitudes might have a negative impact on a sustainable society given that it contributes to gender differences in perceived academic achievement that lead to gender inequities in the future (e.g., occupational status) $[37,39]$. These results are important because low academic achievement and its resulting school failure contribute to high risk situations in adolescence, like completely abandoning the school environment without basic studies and later difficulties to access qualified jobs during adulthood [1,44]. Leaving school without basic qualifications leads to unstable, low skilled jobs with low salaries and unemployment, which contributes to putting people at risk [44]. Completing school successfully is fundamental to access qualified jobs in adulthood. Sexist attitudes constrain opportunities for people and diminish their probability of realizing their potential in life (e.g., certain girls may avoid subjects and careers such as technology or engineering) [71]. In addition, in our study, these relationships were also found in boys (e.g., some boys may devaluate schoolwork). Therefore, gender mainstreaming is the key to achieving a sustainable society [72].

Political leaders have to support the training in equality of boys and girls through consistent equality policies, and the incorporation of the gender perspective should be implemented in the field 
of education, as in other fields, in a transversal way [73]. There is a need to promote actions at school aimed at solving this situation of vulnerability in order to promote socio-emotional education in adolescents, given that sexism restricts the development of potentialities in adolescence [72,74].

Following Díaz-Aguado and Martin (2011) [31], it is necessary to build a new model of relationship between boys and girls, eradicating a traditional model of relationship based on traditional gender roles. Thus, adopting a gender perspective will be fundamental to improving academic achievement and school coexistence, given that hostile sexism has also been related to the physical and verbal aggression of adolescent boys and girls. Likewise, the elimination of sexism should include its various components, cognitive, emotional, and behavioural, taking into account the gender differences in history, making women visible in the study contents, as well as teaching them to detect stereotypes of gender and the sexist construction of identities in their cognitive, behavioural, and emotional dimensions. To break down gender stereotypes about women and men, it will be important to provide female and male role models who break down traditional roles (e.g., female role models in scientific fields) and to provide positive classroom experiences for girls and boys [71]. Finally, it will be necessary to provide interaction experiences between students that are grounded in principals of equal treatment and equal opportunities so they can learn to manage conflicts through cooperation. It is at this point that sexism, with the help of the faculty that legitimises it, can explain the achievement gap in male and female subjects [75-78]. This study and related work can lead to interventions that promote gender equality and improvements in academic achievement.

Author Contributions: Writing—original draft: E.M. and A.L.; Data curation: A.L.; Methodology: E.M.; Supervision: A.T.-P., P.S., and M.V.M.; Writing—review and editing: A.T.-P., P.S., and M.V.M.

Funding: This research was funded by R\&D Projects for Research Teams of Excellence, PROMETEO Program (reference: GVPROMETEUII2015-003), Department of Education of the Region of Valencia; by R\&D Projects of the Ministry for Science and Technology (reference: PSI2016-78242-R-AEI/FEDER, UE); and by AICO R\&D Projects for Research Teams (reference: AICO/2016/090).

Acknowledgments: In this section you can acknowledge any support given which is not covered by the author contribution or funding sections. This may include administrative and technical support, or donations in kind (e.g., materials used for experiments).

Conflicts of Interest: The authors declare no conflict of interest.

\section{References}

1. Verboom, C.E.; Sijtsema, J.J.; Verhulst, F.C.; Penninx, B.W.J.H. Longitudinal associations between depressive problems, academic performance, and social functioning in adolescent boys and girls. Dev. Psychol. 2014, 50, 247-257. [CrossRef] [PubMed]

2. Voyer, D.; Voyer, S.D. Gender differences in scholastic achievement: A meta-analysis. Psychol. Bull. 2014, 140, 1174-1204. [CrossRef] [PubMed]

3. Spears, C.; Leaper, C. Latina and European American girls' experiences with academic sexism and their self-concepts in mathematics and science during adolescence. Sex Roles 2010, 63, 860-870. [CrossRef]

4. Shapiro, J.R.; Williams, A.M. The role of stereotype threats in undermining girls' and women's performance and interest in STEM fields. Sex Roles 2012, 66, 175-183. [CrossRef]

5. Williams, M.; Park, B.; Schmader, T.; Cheryan, S. Charting New Routes for Women at Work: Looking to the Home and Classroom. In Proceedings of the Society for Personality and Social Psychology Conference (SPSP), New Orleans, LA, USA, 27-29 February 2013. Available online: http://search.proquest.com/docview/ 1283017723? accountid=14777 (accessed on 20 February 2014).

6. Friedman, C.; Leaper, C. Sexual-minority college women's experiences with discrimination: Relations with identity and collective action. Psychol. Women Q. 2010, 34, 152-164. [CrossRef]

7. Rodríguez, Y.; Lameiras, M.; Carrera, M.V.; Faílde, J.M. Aproximación conceptual al sexismo ambivalente: Estado de la cuestión [Conceptual approach to ambivalent sexism]. Summa Psicológica UST 2009, 6, 131-142. [CrossRef] 
8. Glick, P.; Fiske, S.T.; Mladinic, A.; Saiz, J.L.; Abrams, D.; Masser, B.; Adetoun, B.; Osagie, J.E.; Akande, A.; Alao, A.; et al. Beyond prejudice as simple antipathy: Hostile and Benevolent Sexism across cultures. J. Pers. Soc. Psychol. 2000, 79, 763-775. [CrossRef] [PubMed]

9. Glick, P.; Lameiras, M.; Fiske, S.T.; Eckes, T.; Masser, B.; Volpato, C.; Manganelli, A.M.; Pek, J.C.; Huang, L.L.; Sakalli-Ugurlu, N. Bad but bold: Ambivalent attitudes toward men predict gender inequality in 16 nations. J. Pers. Soc. Psychol. 2004, 86, 713-728. [CrossRef] [PubMed]

10. Buchanan, N.T.; Settles, I.H.; Hall, A.T.; O'Connor, R.C. A review of organizational strategies for reducing sexual harassment: Insights from the U. S. military. J. Soc. Issues 2014, 70, 687-702. [CrossRef]

11. Garaigordobil, M.; Aliri, J. Relaciones del sexismo con justificación de violencia y con otras formas de prejuicio como la dominancia social y el autoritarismo [Sexism relations with justification of violence and with other forms of prejudice such as social dominance and authoritarianism]. Estudios de Psicología 2013, 34, 127-139. [CrossRef]

12. Masser, B.; Lee, K.; McKimmie, B.M. Bad woman, bad victim? Disentangling the effects of victim stereotypicality, gender stereotypicality and benevolent sexism on acquaintance rape victim blame. Sex Roles 2010, 62, 462-504. [CrossRef]

13. Loveland, J.M.; Lounsbury, J.W.; Welsh, D.; Buboltz, W.C. The validity of physical aggression in predicting adolescent academic performance. Br. J. Educ. Psychol. 2007, 77, 167-176. [CrossRef] [PubMed]

14. Llorca, A.; Richaud, M.C.; Malonda, E. Parenting, peer relationships, academic self-efficacy, and academic achievement: Direct and mediating effects. Front. Psychol. 2017, 8, 2120. [CrossRef] [PubMed]

15. Savage, J.; Ferguson, C.J.; Flores, L. The effect of academic achievement on aggression and violent behavior: A meta-analysis. Aggress. Violent Behav. 2017, 37, 91-101. [CrossRef]

16. Fite, P.J.; Hendrickson, M.; Rubens, S.L.; Gabrielli, J.; Evans, S. The role of peer rejection in the link between reactive aggression and academic performance. Child Youth Care Forum 2013, 42, 193-205. [CrossRef]

17. Swim, J.K.; Hyers, L.L. Sexism. In Handbook of Prejudice, Stereoytping, and Discrimination; Nelson, T.D., Ed.; Taylor \& Francis: New York, NY, USA, 2009; pp. 407-430.

18. Wood, W.; Eagly, A.H. A cross-cultural analysis of the behaviour of women and men: Implications for the origins of sex differences. Psychol. Bull. 2002, 128, 699-727. [CrossRef] [PubMed]

19. Glick, P.; Fiske, S. The ambivalent sexism inventory: Differentiating hostile and benevolent sexism. J. Pers. Soc. Psychol. 1996, 70, 491-512. [CrossRef]

20. Lee, T.L.; Fiske, S.T.; Glick, P. Next gen ambivalent sexism: Converging correlates, causality in context, and converse causality, an introduction to the special issue. Sex Roles 2010, 62, 395-404. [CrossRef]

21. Colás, P. La construcción de la identidad de género: Enfoques teóricos para fundamentar la investigación e intervención educativa. Rev. Investig. Educ. 2007, 25, 151-166.

22. Martínez, I.; Bonilla, A. Sistema Sexo/Género, Identidades y Construcción de la Subjetividad; Publicaciones de la Universitat de València: Valencia, Spain, 2000.

23. Bandura, A.; Barbaranelli, C.; Caprara, G.V.; Pastorelli, C. Self-efficacy beliefs as shapers of children's aspirations and career trajectories. Child Dev. 2001, 72, 187-206. [CrossRef] [PubMed]

24. Valiente, C. El Feminismo de Estado en España: El Instituto de la Mujer (1983-2003) [State feminism in Spain: The Institute for Women (1983-2003)]; Institut d'Estudis Universitaris de la Dona: Valencia, Spain, 2006. Available online: http:/ / digital.march.es/ceacs-ir/en/fedora/repository/ir\%3A2467 (accessed on 10 March 2017).

25. López-Zafra, E.; García-Retamero, R. Do gender stereotypes change? The dynamic of gender stereotypes in Spain. J. Gend. Stud. 2012, 21, 169-183. [CrossRef]

26. Fischer, J.; Anderson, V.N. Gender role attitudes and characteristics of stay-at-home and employed fathers. Psychol. Men Masc. 2012, 13, 16-31. [CrossRef]

27. Lee, I.; Pratto, F.; Li, M. Social relationships and sexism in the United States and Taiwan. J. Cross-Cult. Psychol. 2007, 38, 595-612. [CrossRef]

28. Ayres, M.M.; Friedman, C.K.; Leaper, C. Individual and situational factors related to young women's likelihood of confronting sexism in their everyday lives. Sex Roles 2009, 61, 449-460. [CrossRef] [PubMed]

29. Galleguillos, P.; Olmedo, E. Autoeficacia académica y rendimiento escolar: Un estudio metodológico y correlacional en escolares. [Academic selfefficacy and academic performance: A methodological and correlational study in students]. ReiDoCrea 2017, 6, 156-169. 
30. Instituto Nacional de Evaluación Educativa. Sistema Estatal de Indicadores de Educación 2015. [State System Indicators of Education 2015]; Ministerio de Educación, Cultura y Deporte: Madrid, Spain, 2015. Available online: http:/ / www.mecd.gob.es/inee/publicaciones/indicadores-educativos/Sistema-Estatal.html (accessed on 21 January 2017).

31. Díaz-Aguado, M.J.; Martín, G. Convivencia y aprendizaje escolar en la adolescencia desde una perspectiva de género. Psicothema 2011, 23, 252-259.

32. Fischer, F.T.; Schult, J.; Hell, B. Sex-specific differential prediction of college admission tests: A meta-analysis. J. Educ. Psychol. 2013, 105, 478-488. [CrossRef]

33. Matthews, J.S.; Morrison, F.J.; Ponitz, C.C. Early gender differences in selfregulation and academic achievement. J. Educ. Psychol. 2009, 101, 689-704. [CrossRef]

34. Gibb, S.J.; Fergusson, D.M.; Horwood, L.J. Gender differences in educational achievement to age 25. Aust. J. Educ. 2008, 52, 63-80. [CrossRef]

35. Dardenne, B.; Dumont, M.; Bollier, T. Insidious dangers of benevolent sexism: Consequences for women's performance. J. Pers. Soc. Psychol. 2007, 93, 764-779. [CrossRef] [PubMed]

36. Rudman, L.A.; Heppen, J. Implicit romantic fantasies and women's interest in personal power: A glass slipper effect? Pers. Soc. Psychol. Bull. 2003, 29, 1357-1370. [CrossRef] [PubMed]

37. Montañés, P.; de Lemus, S.; Bohner, G.; Megías, J.L.; Moya, M.; Garcia-Retamero, R. Intergenerational transmission of benevolent sexism from mothers to daughters and its relation to daughters' academic performance and goals. Sex Roles 2012, 66, 468-478. [CrossRef]

38. Barreto, M.; Ellemers, N.; Piebinga, L.; Moya, M. How nice of us and how dumb of me: The effect of exposure to benevolent sexism on women's task and relational self-descriptions. Sex Roles 2010, 62, 532-544. [CrossRef]

39. Leaper, C.; Brown, C.S. Sexism in childhood and adolescence: Recent trends and advances in research. Child Dev. Perspect. 2018, 12, 10-15. [CrossRef]

40. Kuchynka, S.L.; Salomon, K.; Bosson, J.K.; El-Hout, M.; Kiebel, E.; Cooperman, C.; Toomey, R. Hostile and Benevolent Sexism and College Women's STEM Outcomes. Psychol. Women Q. 2018, 42, 72-87. [CrossRef]

41. Merton, R.K. The self-fulfilling prophecy. Antioch Rev. 1948, 8, 193-210. [CrossRef]

42. García-Leiva, P. Identidad de género: Modelos explicativos. Escritos de Psicología 2005, 7, 71-81.

43. Jome, L.M.; Surething, N.A.; Taylor, K.K. Relationally oriented masculinity, gender nontraditional interests, and occupational traditionality of employed men. J. Career Dev. 2005, 32, 183-197. [CrossRef]

44. Bowers, A.J.; Sprott, R.; Taff, S.A. Do we know who will drop out? A review of the predictors of dropping out of high school: Precision, sensitivity, and specificity. High Sch. J. 2013, 92, 77-100. [CrossRef]

45. Masten, A.S.; Roisman, G.I.; Long, J.D.; Burt, K.B.; Obradović, J.; Riley, J.R.; Boelcke-Stennes, K.; Tellegen, A. Developmental cascades: Linking academic achievement and externalizing and internalizing symptoms over 20 years. Dev. Psychol. 2005, 41, 733-746. [CrossRef] [PubMed]

46. Roisman, G.I.; Masten, A.S.; Coatsworth, J.D.; Tellegen, A. Salient and emerging developmental tasks in the transition to adulthood. Child Dev. 2004, 75, 123-133. [CrossRef] [PubMed]

47. Yamawaki, N.; Ostenson, J.; Brown, C.R. The functions of gender role traditionality, ambivalent sexism, injury, and frequency of assault on domestic violence perception: A study between Japanese and American college students. Violence Women 2009, 15, 1126-1142. [CrossRef] [PubMed]

48. De Souza, E.R.; Ribeiro, J. Bullying and sexual harassment among Brazilian high school students. J. Interpers. Violence 2005, 20, 1018-1038. [CrossRef] [PubMed]

49. Ovejero, A.; Yubero, S.; Larrañaga, E.; Navarro, R. Sexismo y comportamiento de acoso escolar en adolescentes [Sexism and school bullying behaviour in adolescents]. Psicol. Conduct. 2013, 21, 157-171.

50. Bonilla, E.; Rivas, E.; Vazquez, J.J. Tolerancia y justificación de la violencia en relaciones de pareja adolescentes. Apunt. Psicol. 2017, 35, 55-61.

51. Cross, E.J.; Overall, N.C.; Hammond, M.D.; Fletcher, G.J. When Does men's hostile sexism predict relationship aggression? The moderating role of partner commitment. Soc. Psychol. Pers. Sci. 2017, 8, 331-340. [CrossRef]

52. Donoghue, C.; Raia-Hawrylak, A. Moving beyond the emphasis on bullying: A generalized approach to peer aggression in high school. Child. Sch. 2015, 38, 30-39. [CrossRef]

53. Björkqvist, K. Sex differences in physical, verbal and indirect aggression: A review of recent research. Sex Roles 1994, 30, 177-188. [CrossRef] 
54. Glick, P.; Hilt, L. From Combative Children to Ambivalent Adults: The Development of Gender Prejudice. In Developmental Social Psychology of Gender; Eckes, T., Trautner, M., Eds.; Erlbaum: Mahwah, NJ, USA, 2000; pp. 243-272.

55. De Lemus, S.; Castillo, M.; Moya, M.; Padilla, J.L.; Ryan, E. Elaboración y validación del Inventario de Sexismo Ambivalente para Adolescentes [Creation and validation of the Adolescent Ambivalent Sexism Inventory]. Int. J. Clin. Health Psychol. 2008, 8, 537-562.

56. Carlo, G.; White, R.M.; Streit, C.; Knight, G.P.; Zeiders, K.H. Longitudinal relations among parenting styles, prosocial behaviors, and academic outcomes in US Mexican adolescents. Child Dev. 2018, 89, 577-592. [CrossRef] [PubMed]

57. Helker, K.; Wosnitza, M. The interplay of students' and parents' responsibility judgements in the school context and their associations with student motivation and achievement. Int. J. Educ. Res. 2016, 76, 34-49. [CrossRef]

58. Kusurkar, R.A.; Ten Cate, T.J.; Vos, C.M.P.; Westers, P.; Croiset, G. How motivation affects academic performance: A structural equation modelling analysis. Adv. Health Sci. Educ. Theory Pract. 2013, 18, 57-69. [CrossRef] [PubMed]

59. Caprara, G.V.; Pastorelli, C. Early emotional instability, prosocial behaviour, and aggression: Some methodological aspects. Eur. J. Pers. 1993, 7, 19-36. [CrossRef]

60. Del Barrio, V.; Moreno, C.; López, R. Evaluación de la agresión e inestabilidad emocional en niños españoles y su relación con la depresión [Assesment of aggression and emotional instability in Spanish children and its relation with depression]. Clinica y Salud 2001, 13, 33-50.

61. Muthén, L.K.; Muthén, B.O. Mplus User's Guide, 6th ed.; Muthén \& Muthén: Los Angeles, CA, USA, 2010.

62. Bollen, K.A. A new incremental fit index for general structural equation models. Soc. Methods Res. 1989, 17, 303-316. [CrossRef]

63. MacKinnon, D.P.; Lockwood, C.M.; Hoffman, J.M.; West, S.G.; Sheets, V. A comparison of methods to test mediation and other intervening variable effects. Psychol. Methods 2002, 7, 83. [CrossRef] [PubMed]

64. Cohen, J. Statistical Power Analysis for the Behavioral Sciences, 2nd ed.; Lawrence Erlbaum Associates: Hillsdale, NJ, USA, 1988.

65. Batista-Foguet, J.M.; Coenders, G. Modelos de Ecuaciones Estructurales [Structural Equation Models]; La Muralla: Madrid, Spain, 2000.

66. Hu, L.T.; Bentler, P.M. Cutoff criteria for fit indexes in covariance structure analysis: Conventional criteria versus new alternatives. Struct. Equ. Model. 1999, 6, 1-55. [CrossRef]

67. Hicks, B.M.; Johnson, W.; Iacono, W.G.; McGue, M. Moderating effects of personality on the genetic and environmental influences of school grades helps to explain sex differences in scholastic achievement. Eur. J. Pers. 2008, 22, 247-268. [CrossRef] [PubMed]

68. Brandt, M.J. Sexism and gender inequality across 57 societies. Psychol. Sci. 2011, 22, 1413-1418. [CrossRef] [PubMed]

69. Shnabel, N.; Bar-Anan, Y.; Kende, A.; Bareket, O.; Lazar, Y. Help to perpetuate traditional gender roles: Benevolent sexism increases engagement in dependency-oriented cross-gender helping. J. Pers. Soc. Psychol. 2016, 110, 55-75. [CrossRef] [PubMed]

70. Montañés, P.; Megías, J.L.; De Lemus, S.; Moya, M. Influence of early romantic relationships on adolescents' sexism/Sexismo en la adolescencia: Influencia de las primeras relaciones de pareja. Rev. Psicol. Soc. 2015, 30, 219-240. [CrossRef]

71. Wang, M.T.; Degol, J.L. Gender gap in science, technology, engineering, and mathematics (STEM): Current knowledge, implications for practice, policy, and future directions. Educ. Psychol. Rev. 2017, 29, 119-140. [CrossRef] [PubMed]

72. Salazar, O. The Fragility of Gender Equality Policies in Spain. Soc. Sci. 2016, 5, 17. [CrossRef]

73. Franz-Balsen, A. Gender and (Un) Sustainability-Can Communication Solve a Conflict of Norms? Sustainability 2014, 6, 1973-1991. [CrossRef]

74. Hall, K.J. “They Believe That Because They Are Women, It Should Be Easier for Them." Subtle and Overt Sexism toward Women in STEM from Social Media Commentary. Ph.D. Thesis, Virginia Commonwealth University, Richmond, VA, USA, 2016. Available online: https:/ / search.proquest.com/docview/1795084464? accountid=14777 (accessed on 18 April 2018).

75. Retelsdorf, J.; Schwartz, K.; Asbrock, F. “Michael can't read!” Teachers' gender stereotypes and boys' reading self-concept. J. Educ. Psychol. 2015, 107, 186. [CrossRef] 
76. Robinson-Cimpian, J.P.; Lubienski, S.T.; Ganley, C.M.; Copur-Gencturk, Y. Teachers' perceptions of students' mathematics proficiency may exacerbate early gender gaps in achievement. Dev. Psychol. 2014, 50, 1262. [CrossRef] [PubMed]

77. Robnett, R.D. Gender bias in STEM fields: Variation in prevalence and links to STEM self-concept. Psychol. Women Q. 2016, 40, 65-79. [CrossRef]

78. Von Haartman, R.; Sammalisto, K.; Lozano, R.; Blomqvist, P. A Longitudinal Comparison of Sustainability Learning between Men and Women in Engineering and Nursing Programmes. Sustainability 2017, 9, 1464. [CrossRef]

(C) 2018 by the authors. Licensee MDPI, Basel, Switzerland. This article is an open access article distributed under the terms and conditions of the Creative Commons Attribution (CC BY) license (http://creativecommons.org/licenses/by/4.0/). 